\title{
Chemotherapy in advanced bladder cancer: current status and future
}

\author{
Nabil Ismaili ${ }^{1 *}$, Mounia Amzerin ${ }^{2}$ and Aude Flechon ${ }^{3}$
}

\begin{abstract}
Bladder cancer occurs in the majority of cases in males. It represents the seventh most common cancer and the ninth most common cause of cancer deaths for men. Transitional cell carcinoma is the most predominant histological type. Bladder cancer is highly chemosensitive. In metastatic setting, chemotherapy based on cisplatin should be considered as standard treatment of choice for patients with good performance status (0-1) and good renal function-glomerular filtration rate (GFR) $>60 \mathrm{~mL} / \mathrm{min}$. The standard treatment is based on cisplatin chemotherapy regimens type MVAC, HD-MVAC, gemcitabine plus cisplatin (GC) or dose dense GC. In unfit patients, carboplatin based regimes; gemcitabine plus carboplatin or methotrexate plus carboplatin plus vinblastine (MCAVI) are reasonable options. The role of targeted therapies when used alone, or in combination with chemotherapy, or in maintenance, was evaluated; targeting angiogenesis seem to be very promising. The purpose of this literature review is to highlight the role of chemotherapy in the management of advanced transitional cell carcinoma of the bladder.
\end{abstract}

\section{1- Introduction}

The incidence of bladder cancer is increasing. An estimated 386,300 new cases and 150,200 deaths from bladder cancer occurred in 2008 worldwide [1]. The highest incidence is observed in Egypt with 37 cases per 100,000 inhabitants [2]. Bladder cancer occurs in the majority of cases in males with a male/female sex ratio of $3: 1$. It represents the seventh most common cancer for men [1]. In France, 10700 new cases were diagnosed in 2000 and accounts for $3.5 \%$ of all cancer deaths. Bladder cancer is the sixth most common cancer (fifth most common cancer in men and seventh in women). In Morocco, bladder cancer was the sixth most common cancer in 2005 according to Rabat registry. The average age of diagnosis is 65 years [3].

Smoking is the most implicated risk factor in western countries, followed by other factors such as polycyclic aromatic hydrocarbons and cyclophosphamide [2]. In East Africa (especially Egypt), chronic infection with Schistosoma haematobium is the most common etiology and is often associated with squamous cell carcinoma [1,2].

Transitional cell carcinoma (TCC) is the most predominant histological type which represents more than $90 \%$ of the cases $[4,5]$.

\footnotetext{
* Correspondence: ismailinabil@yahoo.fr

${ }^{1}$ Medical Oncology, Centre régional d'oncologie, Agadir, Morocco

Full list of author information is available at the end of the article
}

In more than $70 \%$ of the cases, the diagnosis is made at early stage of the disease (stages Ta and T1). Fifty percent of the patients with the disease at advanced stages (T2 or more) experience metastatic relapse.

In metastatic setting, chemotherapy treatment remains the only therapeutic option. It has the objective to alleviate the symptoms, to improve quality of life and to improve survival. In bladder TCC, chemotherapy showed very little progress and the standard MVAC is still the most used regimen and that since several years. New drugs are in the process of development, including those used in targeted therapies for which the role remains to be defined more clearly. This review emphasizes the role of chemotherapy and targeted therapies in metastatic bladder transitional cell carcinoma. Neoadjuvant or adjuvant chemotherapy, and systemic treatment of other histological types such as squamous cell carcinoma, adenocarcinoma, lymphoma, sarcoma and small cell carcinoma are not discussed in this article $[4,5]$.

\section{2- Methods of research}

The literature review was conducted by using PUBMED data base using the following keywords: bladder cancer, transitional cell carcinoma, chemotherapy, cisplatin, and targeted therapies. The abstracts of papers presented at the annual meeting of the American Society of Medical Oncology (ASCO) were also analyzed. All Phase III trials
C Biomed Central

() 2011 Ismaili et al; licensee BioMed Central Ltd. This is an Open Access article distributed under the terms of the Creative Commons Attribution License (http://creativecommons.org/licenses/by/2.0), which permits unrestricted use, distribution, and reproduction in any medium, provided the original work is properly cited. 
were considered. The most important phase II trials have been also included in our article. The research was carried out from January 1980 until July 2011.

\section{3- Prognostic factors in metastatic setting}

Performance status $(>0)$, hemoglobin level $(<10 \mathrm{~g} / \mathrm{L})$, and liver metastasis are recognized as independent factors of poor prognosis in metastatic setting according to a recent prospective study. The median overall survival (OS) of 370 patients treated with chemotherapy for TCC carcinoma of the bladder with $0,1,2$ and 3 factors were 14.2, 7.3, 3.8, and 1.7 months $(\mathrm{P}<0.001)$, respectively [6].

Prognostic factors helps better to define the therapeutic strategy. For patients with 2 or 3 factors, it is suggested that aggressive chemotherapy should be avoided because of an increased risk of toxicity [6].

\section{4- Chemotherapy in metastatic disease}

\section{1- Single agents}

Bladder TCC are chemosensitive tumors. However, the response to a single agent is limited. Cisplatin is one of the most active drugs that give the highest overall response rate (ORR). Other drugs are also active (Table 1 ).

\section{2- Multi agents chemotherapy}

\subsection{1- Cisplatin-based chemotherapy}

4.2.1.1-Conventional regimens The first protocols based on cisplatin (CMV: cisplatin, cyclophosphamide and vinblastine; and CISCA: cisplatin, doxorubicin and cyclophosphamide) induced 12 to $78 \%$ ORR. The two protocols CMV and CISCA were widely used in the 1980 s but did not show superiority in survival versus cisplatin alone [7-10].

Since 1990, the MVAC has been considered as a standard first-line therapy in metastatic disease. This regimen was for the first time studied in a nonrandomized phase II trial by Sternberg and colleagues in 1985 [11,12] and

Table 1 ORR of single agents

\begin{tabular}{cc}
\hline Drogues & ORR \\
\hline Cisplatin & $33 \%$ \\
Methotrexate & $29 \%$ \\
Doxorubicin & $23 \%$ \\
5-fluoro-uracil & $35 \%$ \\
Vinblastine & - \\
Cyclophosphamide & - \\
Mitomycine C & $21 \%$ \\
Carboplatin & $12-14 \%$ \\
Gemcitabine & $24-28 \%$ \\
Paclitaxel & $10-40 \%$ \\
Docetaxel & $13-31 \%$ \\
Vinflunine & $15 \%$ \\
Eribulin & $38 \%$ \\
\hline
\end{tabular}

concerned 25 patients. They showed a sustained ORR in $71 \%$ of the cases and $50 \%$ of complete responses (CR). Two randomized phase III trials demonstrated the superiority of the MVAC to CISCA and CDDP, respectively, both in ORR, and in OS $[13,14]$. The MVAC is efficient, but particularly toxic. In the phase II study [11], the combination induced one toxic death and 4 febril neutropenias (16\%), in addition to vomiting, anorexia, mucositis (grade $3-4$ in $22 \%$ of the cases), alopecia and renal insufficiency.

To improve the results obtained with the MVAC, an intensification of this same protocol as HD-MVAC was tested in a phase III EORTC trial including more than 250 patients. In the experimental arm, all drugs were administered in day 1 and day 14. Prevention of toxicity was based on the routine use of Granulocyte Colony-Stimulating Factors (GCSF). Although the OS which represents the primary end point of the study, was identical in the two arms at 7.3 years median follow-up. However, the study showed that the intensification of the protocol improved CR (25 vs. 10\%) and progression-free survival (PFS) (9.5 vs. 8.1 months, $\mathrm{p}=0.03$ ). Survivals at 2 and 5 years were also better ( $37 \%-22 \%$ vs. $25-22 \%$, respectively). In addition, the systematic use of GCSF made the HDMVAC better tolerated. While the primary end point was not achieved, the intensified MVAC is widely used in metastatic settings $[15,16]$.

Table 2 summarizes the results of the most important phase III trials investigating first line chemotherapy in advanced bladder TCC.

\subsubsection{2- Second generation drugs}

* Gemcitabine based regimens

In the 1990s, gemcitabine was a new molecule in the treatment of bladder TCC.

The first phase II trials evaluating the use of gemcitabine as single agent showed an improvement of ORR by 24 to $28 \%$. The combination of gemcitabine with cisplatin (GC) has further improved these results with higher ORR (57\%) and CR (15 to 21\%) [17].

Based on these encouraging results, a phase III trial was conducted to compare the GC protocol to the standard MVAC. The study was designed to demonstrate superiority of the experimental arm in OS. The results showed no improvement of OS (MVAC: 14.8 months vs. GC: 13.8 months) and ORR (MVAC: 45.7 vs. GC: $49.4 \%$ ). But due to the better safety profile, the GC was considered not inferior to MVAC $[18,19]$.

A recent phase III trial compared the intensified HD$\operatorname{MVAC}(\mathrm{n}=118)$ to the dense dose GC (DD-GC) ( $\mathrm{n}=$ 57) (G: $2500 \mathrm{mg} / \mathrm{m}^{2}, \mathrm{C}: 70 \mathrm{mg} / \mathrm{m}^{2} \mathrm{q} 2 \mathrm{wks}$ ). The results were presented this year at the ASCO 2011 and showed that efficacy was similar in both treatments $(\mathrm{ORR}=47.4$ vs. $47.4 \%$, respectively: $\mathrm{p}=0.9$; and $\mathrm{OS}=18.4$ vs. 20.7 months, respectively: $\mathrm{p}=0.7$ ), however, the safety profile was slightly better in favor to DD-GC [20]. 
Table 2 Randomized phase III trials investigating first-line chemotherapy regimens in metastatic bladder TCC

\begin{tabular}{|c|c|c|c|c|c|c|}
\hline Authors & $\begin{array}{l}\text { Journal } \\
\text { or } \\
\text { meeting }\end{array}$ & Year & Treatments & No & Results & Toxicity \\
\hline Logothetis [13] & $\mathrm{JCO}$ & 1990 & $\begin{array}{l}\text { MVAC vs. } \\
\text { CISCA }\end{array}$ & 120 & $\begin{aligned} \text { Sup: } \mathrm{ORR} & =65 \text { vs. } 46 \%, \mathrm{p}<0.05 \\
\text { and } \mathrm{OS} & =62.6 \text { vs. } 48.3 \text { weeks }\end{aligned}$ & Sup \\
\hline Loehrer [14] & $\mathrm{JCO}$ & 1992 & $\begin{array}{l}\text { MVAC vs. } \\
\text { Cisplatin }\end{array}$ & 146 & $\begin{array}{l}\text { Sup: ORR }=39 \text { vs. } 12 \%, p<0.0001 ; \\
\text { PFS }=10 \text { vs. } 4.3 \text { months, and OS = } \\
12.5 \text { vs. } 8.2 \text { months }\end{array}$ & Sup \\
\hline Von der Maase $[18,19]$ & $\mathrm{JCO}$ & 2000 & $\begin{array}{l}\text { MVAC VS. } \\
\quad \text { GC }\end{array}$ & 405 & Equivalents & $\begin{array}{l}\text { more neutropenic sepsis ( } 12 \% \text { vs. } 1 \% ; P<0.001) \\
\text { and more grade } 3-4 \text { mucositis ( } 22 \% \text { vs. } 1 \% ; P= \\
0.001 \text { ) on the MVAC arm }\end{array}$ \\
\hline Sternberg $[15,16]$ & $\mathrm{JCO}$ & 2001 & $\begin{array}{l}\text { HD-MVAC } \\
\text { VS. MVAC }\end{array}$ & 259 & Equivalents & $\begin{array}{l}\text { less neutropenic fever ( } 10 \% \text { vs. } 26 \% \text {; } P<0.001 \text { ) } \\
\text { and mucositis on the HD-MVAC arm }\end{array}$ \\
\hline Bamias [26] & $\mathrm{JCO}$ & 2004 & $\begin{array}{l}\text { MVAC Vs. } \\
\text { DC }\end{array}$ & 120 & Sup & \\
\hline Dreicer [31] & Cancer & 2004 & $\begin{array}{l}\text { MVAC vs. } \\
\text { PCa }\end{array}$ & 85 & Interrupted early & Sup \\
\hline Bellmunt [48] & ASCO & 2007 & PCG vs. GC & 627 & Equivalents & Sup \\
\hline De Santis [37] & ASCO & 2010 & $\begin{array}{l}\text { GCa vs. } \\
\text { MCAVI }\end{array}$ & 238 & Equivalents & $\operatorname{lnf}$ \\
\hline Bamias [20] & ASCO & 2011 & $\begin{array}{l}\text { DD-GC vs. } \\
\text { HD-MVAC }\end{array}$ & 175 & Equivalents & $\operatorname{lnf}$ \\
\hline
\end{tabular}

Abbreviations. JCO: Journal of Clinical Oncology; MVAC: methotrexate-vinblastine-doxorubicin-cisplatin; CISCA: cisplatin-cyclophosphamide-doxorubicin; DC: docetaxel plus cisplatin; PCG: paclitaxel-cisplatin-gemcitabin; PCa: paclitaxel plus carboplatin; MCAVI: methotrexate-carboplatin-vinblastine; HD: high dose; DD: dose dense; ORR: objective response rate; OS: overall survival; PFS: progression free survival. Sup = superior; Inf = inferior.

\section{*Taxanes based regimens}

Cisplatin was also tested in phase II studies with other new drugs, particularly with taxanes (Table 3). The combination of cisplatin with paclitaxel and cisplatin with docetaxel improved ORR by $50-70 \%$ and $52-62 \%$ respectively [21-25].

We note that these combinations remain inferior to the standard chemotherapy as was proven by the phase III randomized study conducted by the Hellenic Cooperative Oncology Group comparing docetaxel-cisplatin to MVAC. The standard protocol was superior in ORR (54.2\% vs. $37.4 \%, \mathrm{p}=0.017)$, time to progression $(\mathrm{TTP})$ (9.4 vs. 6.1 months, $\mathrm{p}=0.003)$ and $\mathrm{OS}(14.2$ vs. 9.3 months, $\mathrm{p}=0.026$ ) [26].

Table 3 Phases II trials evaluating taxanes based doublets

\begin{tabular}{|c|c|c|c|}
\hline Authors & Treatments & $\mathbf{N}$ & Results \\
\hline Burch et al [21] & PC & 34 & $\mathrm{ORR}=70 \%$ \\
\hline Dreicer et al [22] & PC & 52 & $\begin{array}{c}\text { ORR }=50 \% \\
\text { OS }=10.6 \text { months }\end{array}$ \\
\hline Dimopoulos et al [23] & $\mathrm{DC}$ & 66 & $\begin{array}{c}\text { ORR }=52 \% \\
T T P=5 \text { months } \\
\text { OS }=8 \text { months }\end{array}$ \\
\hline DelMuro et al [24] & DC & 38 & $\begin{array}{c}\text { ORR }=58 \% \\
\text { TTP }=6.9 \text { months } \\
\text { OS }=10.4 \text { months. }\end{array}$ \\
\hline Sengelov et al [25] & $\mathrm{DC}$ & 25 & $\begin{array}{c}\text { ORR }=60 \% \\
\text { OS }=13.6 \text { months }\end{array}$ \\
\hline
\end{tabular}

Abbreviations. PC: paclitaxel-cisplatin; DC: docetaxel-cisplatin; ORR: overall response rate; OS: overall survival; TTP: time to progression.

\subsection{2- Chemotherapy doublets based on other platinum drugs}

Carboplatin is not as efficient as cisplatin. But has the advantage of being easily administered and better tolerated. Therefore, carboplatin-based protocols should be considered in patient ineligible (unfit) for cisplatin-based chemotherapy (Table 4) [27].

Carboplatin has been tested with paclitaxel in several phase II trials and permitted to achieve more than $63 \%$ ORR, but CR was limited as compared to cisplatin based protocols. Based on these frustrating results and other data suggesting the limited activity of this protocol $[29,30]$, a phase III study was stopped early due to lack of recruitment. This study was designed to compare paclitaxel-carboplatin to MVAC [31].

Gemcitabine used in combination with carboplatin showed significantly lower results than cisplatin plus gemcitabine. ORR was high (59\%), but the comparison with the GC showed that the standard arm was significantly better according to the results of one randomized phase II study [32-35].

Oxaliplatin is another platinum drug which showed only marginal activity as monotherapy [36].

In another hand, the EORTC conducted a phase III trial comparing unfit patients having metastatic TCC, the protocol based on carboplatin (AUC 4.5 on day) - gemcitabine $\left(1000 \mathrm{mg} / \mathrm{m}^{2}\right.$ on day 1 and day 8$)(\mathrm{GCa})$, repeated every 21 days, to the protocol M-CAVI [methotrexate (30 $\mathrm{mg} / \mathrm{m}^{2}$ on day 1 , day 15 , and day 22 ), carboplatin (AUC 4.5 on day 1 ) and vinblastine $\left(3 \mathrm{mg} / \mathrm{m}^{2}\right.$ on day 1 , 
Table 4 Phases II trials evaluating carboplatin based doublets

\begin{tabular}{cccc}
\hline Auteur & Treatment & No & Results \\
\hline Redman et al [28] & PCa & 35 & ORR $=51 \% ;$ OS $=9.5$ months \\
Small et al [29] & PCa & 29 & ORR $=20,7 \% ;$ TTP $=4$ months; OS $=9$ months \\
Vaughn et al [30] & PCa & 33 & ORR $=50 \%$ \\
Bellmunt et al [32] & GCa & 16 & ORR $=44 \%$ \\
Nogue-Aliguer et al [33] & GCa & 41 & ORR = 56.1\%; PFS $=7.2$ months; OS $=10.1$ months \\
Shannon et al [34] & GCa & 17 & ORR = 58.8\%; PFS $=4.6$ months; OS $=10.5$ mois \\
Dogliotti et al [35] & GCa vs. GC (Randomized phase II) & 110 & Efficacy: CR: 1.8\% vs. 14.5\%; OS: 9.8 vs. 12.8 months \\
& & & Toxicity: Equivalent.
\end{tabular}

Abbreviations. PCa: paclitaxel-carboplatin; GCa: gemcitabine-carboplatin; GC: gemcitabine-cisplatin; ORR: objective response rate; OS: overall survival; PFS: progression free survival.

day 15 , and day 22)], repeated every 28 days. The results presented at ASCO 2010, confirmed the equivalence in OS between the 2 treatments, with a better toxicity profile in favor to the GCa protocol [37].

\subsection{3- Doublets without platinum drugs}

Data on the effectiveness of drugs, in patients with good or poor condition are not sufficient. The literature reports only phase II trials with low number of patients. The protocol which is most studied is based on gemcitabine in combination with other molecules.

Gemcitabine-paclitaxel combination appears to produce a significant improvement. This protocol improved ORR to $40-60 \%$ [38-40]. Several schemes were tested. A phase II study investigated the gemcitabine-paclitaxel weekly, showed an ORR of up to $69 \%$ (42\% of CR), however the rate of grade 3-4 pulmonary toxicity and toxic death is high. Therefore, the authors recommended disregard the use of this regimen in practice [41].

With docetaxel, gemcitabine is active and well tolerated. In 3 different phase II studies the ORR was between 30 and $50 \%$ [42-44].

Gemcitabine was also evaluated in association with pemetrexed in 2 phases II trials in 64 and 44 patients, respectively. The ORR was 20 and $28 \%$. But this combination was very hematotoxic. In addition, 2 toxic deaths were reported $[45,46]$.

\subsection{4- Triplets}

To improve the ORR, several phase II and III studies were conducted by testing the addition of a third drug to the standard protocols used in practice.

Paclitaxel, in combination with GC, was the first triplet studied in a phase II trial conducted by Bellmunt, showing $77.6 \%$ ORR in 58 patients $(\mathrm{ORR}=27.6 \%$ and $\mathrm{PR}=$ $50 \%$ ) [47]. Therefore, the authors concluded the feasibility and the activity of this triple association. This was the background of a phase III randomized trial developed by the EORTC group, comparing the same protocol to the standard protocol GC. The authors considered the OS as a primary endpoint. Even with significant superiority in ORR for the experimental arm (57.1 vs. $46.4 \%, \mathrm{p}=0.02)$, the primary objective of the study was not achieved
$(\mathrm{OS}=15.7$ vs. 12.8 months, $\mathrm{p}=0.12, \mathrm{PFS}=8.4$ vs. 7.7 months, $\mathrm{p}=0.01$ ) [48].

Bajorin has evaluated the feasibility and safety of paclitaxel, ifosfamide and cisplatin triplet administered every 3 weeks in a phase II study. Among 44 evaluable patients, the rate of CR was $23 \%$ and PR was $45 \%$. The median survival was 20 months [49].

Paclitaxel-carboplatin-gemcitabine triplet was investigated in two phase II trials involving patients in the first line in one trial, and in 1st/2nd lines in another trial. ORRs and CR were equal to $43-68 \%$, and $32-12 \%$, respectively. The OS was equal to 14.7 and 11 months, respectively [50,51].

Other combinations including paclitaxel have also been reported in the literature, and showed promising activity and acceptable toxicity profile, but, more investigations are required in clinical trials [52-54].

The cisplatin-epirubicin-docetaxel triplet gave 30\% complete responses in first line in 30 evaluable patients. The ORR was $66.7 \%$. The median survival reached 14.5 months. Even for patients with PS 3, the overall safety profile was comparable to MVAC [55].

\subsection{5- Sequential protocols}

Based on the effectiveness of the sequential regimens in breast cancer, this option was studied in metastatic bladder cancer.

In a phase II trial, the doublet doxorubicin-gemcitabine was evaluated in sequence with the triplet paclitaxel-ifosfamide-cisplatin in previously untreated patients $(n=60)$ with advanced TCC, with the systematic use of GCSF. In the final results recently published, the authors conclude that the regimen is active; however, it is associated with high rate of grade 3-4 hematological toxicity and does not clearly offer a benefit compared with the standard treatments [56]. In another trial, 25 patients with advanced urothelial carcinoma who were ineligible for cisplatin, received doses-dense sequential treatment with doxorubicin plus gemcitabine followed by paclitaxel plus carboplatin. ORR was 56\% and the treatment was well tolerated [57].

Table 5 summarizes the most important prospective studies evaluating the role of triplet and sequential regimens. 
Table 5 Phases I/II trials evaluated the triplets and sequential regimens

\begin{tabular}{|c|c|c|c|c|c|}
\hline Authors & Treatments & $\begin{array}{c}\text { Trial } \\
\text { phase }\end{array}$ & No & Efficacy & Toxicity \\
\hline Bellmunt et al [47] & CPG & $|/| \mid$ & 58 & $\begin{array}{c}\text { ORR }=77.6 \% ; C R=27.6 \% ; P R=50 \% ; \\
\text { OS }=24 \text { months. }\end{array}$ & $\begin{array}{l}\text { Hematological+++ (Grade } 3 / 4 \text { neutropenia and } \\
\text { thrombocytopenia in } 55 \% \text { and } 22 \% \text {, respectively) }\end{array}$ \\
\hline Bajorin et al [49] & ITP & $\|$ & 44 & $C R=23 \% . ; P R=45 \% . ; O S=20$ months. & Well tolerated \\
\hline Hussain et al [50] & $\mathrm{CaPG}$ & $\|$ & 49 & $\begin{array}{l}C R=32 \% ; P R=36 \% ; O S=14.7 \\
\text { months; } 1 \text { years survival }=59 \%\end{array}$ & Hematological+++ \\
\hline Hainsworth et al [51] & CaPG & $\|$ & $\begin{array}{l}60(7 \% \text { in } \\
2 \text { 2nd line) }\end{array}$ & $\begin{array}{c}\mathrm{ORR}=43 \% ; C R=12 \% ; \text { OS }=11 \\
\text { months; }\end{array}$ & $\begin{array}{c}\text { Hematological+++ (10\% of febril neutropenia) } \\
\text { One toxic death }\end{array}$ \\
\hline Edelman et al [52] & $\begin{array}{l}\text { M-CaP } \\
\text { (GCSF) }\end{array}$ & $|/| \mid$ & 33 & ORR $=56 \% ;$ OS = 15.5 months. & Hematological and neuropathy \\
\hline Tu et al [53] & $\mathrm{M}-\mathrm{CP}$ & $\|$ & $\begin{array}{c}25\left(2^{\text {nd }}\right. \\
\text { line })\end{array}$ & $P R=40 \% ; C R=0 \%$ & Acceptable \\
\hline Law et al [54] & M-GP & $\|$ & 20 & $\begin{array}{c}\mathrm{ORR}=45 \%(\mathrm{CR}=6 ; \mathrm{PR}=3) ; \mathrm{OS}=18 \\
\text { months; } \mathrm{PFS}=6.3 \text { months }\end{array}$ & Neutropenia+++ (1 toxic death) \\
\hline Pectasides et al [55] & EDC & $\|$ & 30 & $\begin{array}{c}\text { ORR }=66.7 \%(C R=30 \% ; P R=36.7 \%) \\
\text { OS = } 14.5 \text { months. }\end{array}$ & Hematological (4 episodes of febril neutropenia) \\
\hline $\begin{array}{l}\text { Milowsky Ml et al } \\
{[56]}\end{array}$ & $\begin{array}{l}\text { AG } \rightarrow \text { ITP } \\
\text { with GCSF }\end{array}$ & $\|$ & 60 & $\begin{array}{l}\mathrm{ORR}=73 \%(C R=35 \% \text { and } \mathrm{PR}=38 \%) \\
\mathrm{PFS}=12.1 \text { months; OS }=16.4 \text { months }\end{array}$ & $\begin{array}{l}\text { Myelosupression (grade 3-4): 68\% } \\
\text { Febril neutropenia (25\%) }\end{array}$ \\
\hline Galsky MD et al [57] & $\begin{array}{l}\mathrm{AG} \rightarrow \mathrm{ITCa} \\
\text { with GCSF }\end{array}$ & $|/| \mid$ & 21 & $\mathrm{ORR}=56 \%(C R=5 ; \mathrm{RP}=9)$ & $\begin{array}{l}\text { Myelosupression (grade } 3-4 \text { ): } 28 \% \\
\text { Febril neutropenia: } 8 \%\end{array}$ \\
\hline
\end{tabular}

Abbreviations. ITP: ifosfamide-paclitaxel-cisplatin; CPG: cisplatin-paclitaxel-gemcitabine; CaPG: carboplatin-paclitaxel-gemcitabine; M-CaP: methotrexatecarboplatin-paclitaxel; M-CP: methotexate-cisplatin-paclitaxel; M-GP: methotrexate-gemcitabine-paclitaxel; EDC: epirubicin-docetaxel-cisplatin; AG: doxorubicincisplatin; ITCa: ifosfamide-paclitaxel-carboplatin; CR: complete response; PR: partial response; ORR: objective response rate; OS: overall survival; PFS: progression free survival.

\section{3- Second and third line chemotherapy}

After failure of cisplatin-based first-line therapy, there was no consensus in the management of cisplatin resistant disease.

Taxanes (paclitaxel and docetaxel), vinflunine, and antifolate compounds (trimetrexate, piritrexim, and pemetrexed) resulted in 7 to $23 \%$ ORR. The FOLFOX 4 was also studied in a phase II trial and resulted in 19\% ORR [58-60]. In a recent published case study, the authors obtained a CR with FOLFOX4 chemotherapy in a metastatic urothelial cancer patient, after failure of GC combination [61].

The first phase III trial on cisplatin refractory setting compared vinflunine to best supportive care. Vinflunine is a semi-synthetic, vinca alkaloid compound that targets the microtubules. It was used at a dose of $320 \mathrm{mg} / \mathrm{m}^{2}$ repeated every 21 days until progression or intolerance. Compared with the control arm, vinflunine was superior in OS > 2 months, however significant grade 3-4 hematologic toxicities (6\% of febril neutropenia, one toxic death, anemia, and thrombocytopenia) were noted [62].

The second phase III trial was designed to compare a short-term (six cycles: arm A) versus prolonged (until progression: arm B) second-line combination chemotherapy of gepcitabine-paclitaxel. On prolonged treatment, more patients experienced severe anemia (arm A: 6.7\% versus arm B: $26.7 \%$ grade 3-4 anemia; $\mathrm{P}=0.011$ ). Therefore, the authors concluded that it was not feasible to deliver a prolonged regimen. However, a high response rate of $40 \%$ makes the short protocol (6 cycles) a promising second line treatment option for patients with metastatic TCC [63].

\section{4- New molecule}

Eribulin is a new agent targeting the microtubules, being tested in several primary tumors. In advanced or metastatic TCC, this molecule was evaluated in a phase II trial, and showed a very interesting antitumor activity in front line with $38 \%$ ORR. The PFS was estimated to 3.9 months and the safety profile was acceptable (neutropenia, neuropathy, hypoglycemia, and hyponatremia) [64]. Based on these results, a phase III trial is undergoing to compare the standard GC to the combination of GC to Eribulin.

\section{5- Targeted therapies}

Despite the promising results obtained by chemotherapy based on MVAC or GC, the majority of patients die of metastatic disease.

The new progress in molecular biology has prompted the investigators to evaluate several molecules in metastatic bladder TCC.

Overexpression of several receptors such as the VEGFR (vascular endothelial growth factor receptor) on endothelial cells, the EGFR (epidermal growth factor receptor, the PDGFR (platlet derived growth factor receptor), and the FGFR (fibroblast growth factor receptor), on tumor cells, led the investigators to evaluate the efficacy and safety of new molecules targeting signaling pathways controlled by these proteins in metastatic setting (Figure 1). 


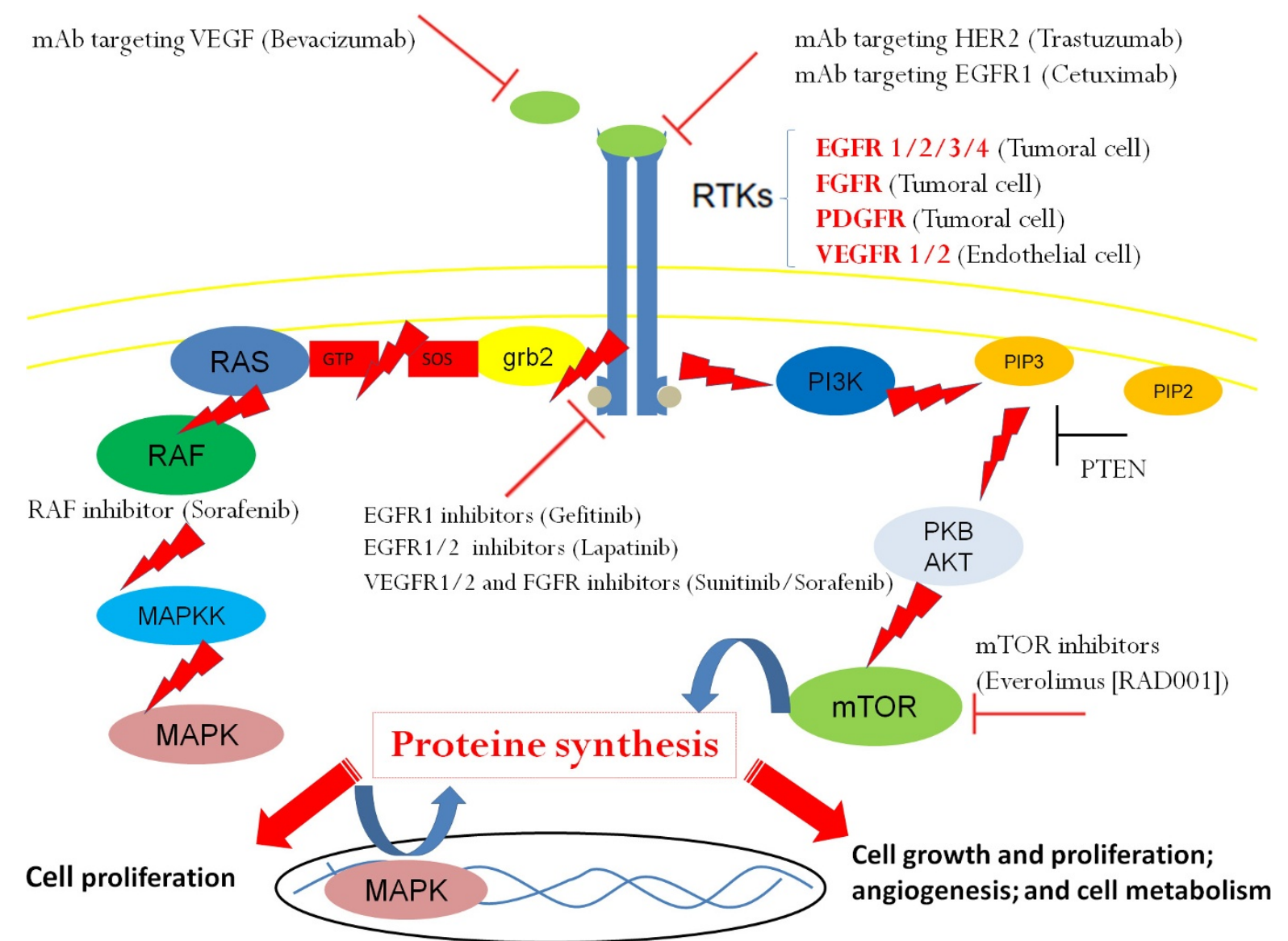

Figure 1 Deregulated signaling pathways and targeted therapy in bladder cancer. Abbreviations: EGFR, Epithelial Growth Factor Receptor; VEGFR, Vascular Endothelial Growth Factor R; FGFR: Fibroblast Growth Factor Receptor; mTOR: mammalian Target of Rapamycin.

The role of targeted therapy alone, in combination with chemotherapy, and in maintenance was evaluated using different molecules (bevacizumab, sunitinib, sorafenib, pazopanib, dovitinib, vandetanib, trastuzumab, cetuximab, erlotinib, lapatinib, everolimus, bortezomibe) (Table 6) [65-84].

\subsection{1- Targeting angiogenesis}

Increased signaling through VEGFR and FGFR characterizes many TCC tumors and increased tumor vascularization. Angiogenesis is a very important step to tumor growth, invasion and metastasis. Therefore, targeting angiogenesis is a very interesting strategy which can be achieved by the use of monoclonal antibodies or by using small molecules tyrosine kinase inhibitors.

\section{(A) Monoclonal antibodies}

\section{"Bevacizumab}

Bevacizumab is a humanized monoclonal antibody (mAb) targeting the VEGF (Vascular Endothelial Factor) which has been approved by FDA in combination with chemotherapy as a standard treatment in first line and second line in different metastatic tumors. In bladder TCC, bevacizumab (15 mg/kg on day 1) was evaluated in first line treatment in combination with GC protocol (gemcitabine 1250 on D1 and D8 and cisplatin $70 \mathrm{mg} / \mathrm{m}^{2}$ on D1, the cycle was repeated every 21 days) in a phase II trial (45 patients). Mature data presented at ASCO 2010 showed similar results in ORR and PFS to those obtained by the GC protocol, but OS was superior estimated to 20.4 months. A phase III trial comparing GC to GC plus bevacizumab is undergoing [66].

\section{(B) Small molecules}

"SU11248 Sunitinib Sutent ${ }^{\circledR}$

Sunitinib is a small molecule playing as a multi target intracellular tyrosine kinases inhibitor by inhibiting multiple receptors (EGFR, VERFR-1/2, C-KIT, PDGFR $\alpha / \beta$ ) and the FLT3 and RET kinases. This drug has been approved by the FDA in the front line treatment of metastatic renal cell carcinoma and in the second line treatment of GIST (gastrointestinal stromal tumors) after failure of imatinib. Sunitinib has been tested in bladder cancer as single agent, in combination with chemotherapy, and in maintenance, and showed an interesting antitumor activity [67-71]. In a phase II trial presented at ASCO 2010, the Sunitinib was evaluated in association 
Table 6 Phase II trials evaluating the role of targeted therapies

\begin{tabular}{|c|c|c|c|c|c|c|}
\hline Organisations & Treatments & $\begin{array}{c}\text { Trial } \\
\text { phase }\end{array}$ & Line & No & Results & $\begin{array}{l}\text { Most common grades } 3-4 \\
\text { toxicities }\end{array}$ \\
\hline $\begin{array}{l}\text { Hoosier Oncology } \\
\text { Group [66] }\end{array}$ & $\begin{array}{c}\mathrm{GC}+ \\
\text { Bevacizumab }\end{array}$ & $\|$ & $1 s t$ & 43 & $\begin{array}{c}\mathrm{ORR}=72 \%(21 \% \text { de; } \mathrm{CR} \text { et } 51 \% \text { de RP); PFS }=8.2 \\
\text { months; } \mathrm{OS}=20.4 \text { months }\end{array}$ & $\begin{array}{l}\text { Hematological, } \\
\text { thromboembolism }\end{array}$ \\
\hline USA (Texas) [70] & $\begin{array}{c}\mathrm{GC}+ \\
\text { sunutinib }\end{array}$ & $\|$ & $1 s t$ & 15 & Interrupted for toxicity & Hematological++ \\
\hline Espagne [71] & Sunitinib & $\|$ & $1 s t$ & 37 & $\mathrm{DC}=8 \% ; \mathrm{PFS}=5.9$ months & $\begin{array}{l}\text { Fatigue, Hypertention, } \\
\text { Hand-Foot syndrom }\end{array}$ \\
\hline Allemagne [73] & $\begin{array}{c}\mathrm{GC}+ \\
\text { sorafenib }\end{array}$ & $\| R$ & $1 s t$ & 85 & ORR $=82 \%$ vs. $78 \% ;$ PFS $=6.3$ mois vs. 7.2 months & Hematological \\
\hline NCl Trial [79] & $\begin{array}{l}\text { Trastuzumab } \\
+\mathrm{CaPG}\end{array}$ & $\|$ & $1 s t$ & $\begin{array}{c}44 \\
(\text { HER2++ } \\
+)\end{array}$ & $\begin{array}{c}\mathrm{ORR}=70 \%(11 \% \text { de } \mathrm{CR} \text { et } 59 \% \text { de RP }) ; \mathrm{OS}=14 \\
\text { months }\end{array}$ & $\begin{array}{l}\text { Hematological, sensory } \\
\text { neuropaty, cardiac }\end{array}$ \\
\hline CALGB [81] & $\begin{array}{l}\text { Gefitinib + } \\
\text { GC }\end{array}$ & $\|$ & $1 s t$ & 58 & $\begin{aligned} \text { ORR }= & 48 \%, ; P F S=7 \text { months } s_{, ;} \text {OS }=15 \text { months; } \\
& \text { Equivalents results to GC et MVAC }\end{aligned}$ & $\begin{array}{l}\text { Hematological, skin rash, } \\
\text { diarrhea, }\end{array}$ \\
\hline Allemagne [82] & Lapatinib & $\|$ & $\begin{array}{l}\text { 2nd and } \\
\text { more }\end{array}$ & 59 & $\mathrm{PR}=3 \% ; \mathrm{S}=12 \% ; \mathrm{PFS}=8.6$ weeks & $\begin{array}{l}\text { Diarrhea, vomiting, } \\
\text { dehydration }\end{array}$ \\
\hline Italy and USA [84] & Everolimus & $\|$ & 2nd & 45 & $\mathrm{PR}=8 \% ; \mathrm{PFS}=3.3$ months; OS $=10.5$ months & $\begin{array}{l}\text { Hematological, fatigue, } \\
\text { metabolic, mucositis }\end{array}$ \\
\hline
\end{tabular}

Abbreviations. GC: gemcitabine-cisplatin; ORR: objective response rate; RC: complate response; PR: partial response; S: stabilisation; DC: disease control; PFS: progression free survival; OS: overall survival; CaPG: paclitaxel-gemcitabine-carboplatin.

with the GC, but the trial was stopped because of high rate of hematological toxicity [70]. In another phase II study also presented at ASCO 2010, including 33 unfit patients treated with single agent sunitinib, the TTP was estimated to 4.8 months and the clinical benefit to $67 \%$, confirming the role of the angiogenic pathway as an interesting target in the treatment of bladder TCC [71].

"BAY43-9006 Sorafenib Nexavar ${ }^{\circledR}$

Sorafenib is another small multi-target molecule (B-Raf, c-Raf, VEGFR-2/3, VEGFR-3, PDGFR- $\beta$ ) which has been approved by the FDA in second line treatment of metastatic renal cell carcinoma after failure of immunotherapy, and in first line treatment of advanced hepatocellular carcinoma, Child A. It has been tested in bladder TCC as single agent and in combination with chemotherapy in first and second line metastatic disease. However, Sorafenib didn't have activity in monotherapy [72], and in the combination with GC. Sorafenib did not improve the results of the standard GC in a recent randomized phase II trial [73].

*TKI258 Dovitinib

Dovitinib is an oral drug that inhibits angiogenic factors, including the FGFR and the VEGFR. TKI258, administered at a dose of $500 \mathrm{mg} /$ day taken 5 days per week dosing schedule, was evaluated in phase II trial in second line treatment. The results of this trial, presented this year at the ASCO 2011, are promising [74].

\subsection{2- EGFR inhibitors}

\section{(A) Monoclonal antibodies}

* Trastuzumab

The amplification of the HER2/neu oncogene has been correlated in bladder cancer to a more aggressive disease [75]. Bladder tumors with HER2 amplification represent $10-50 \%$ of cases [76-78].
In a multicenter U.S. Phase II study, trastuzumab was tested in combination with paclitaxel-carboplatin-gemcitabine triplet. The study included 109 patients, 57 (52\%) had HER2 amplification, and 54 of 57 patients were treated with trastuzumab. The main toxicities were hematological, neurological and cardiac. ORR rate was equal to $70 \%$. The TTP was 9.3 months and OS was14.1 months [79].

\section{(B) Small molecules}

\section{* Gefetinib ZD1839 IRESSA ${ }^{\circledR}$}

Gefitinib is a small molecule tyrosine kinase inhibitor that has been recently approved by the FDA in the front line treatment of metastatic non small cell lung cancer with activated EGFR mutation. In bladder cancer, it was in the first time evaluated as monotherapy in second-line therapy. This study showed no ORR. Median PFS was limited [80]. Gefitinib was also studied with GC in first line treatment. The results were similar to the GC and MVAC (CALGB 90102) [81].

* GW 572016 Lapatinib Tykerb ${ }^{\circledR}$

Lapatinib is a small molecule tyrosine kinase inhinitor allowing the inhibition of HER1 and HER2 receptors. This molecule has been approved by the FDA in the treatment of metastatic breast cancer with HER2 amplification. In one study, 59 patients with HER2 and/or EGFR amplifications were treated after failure of one or more therapeutic lines. In this phase 2 trial, only one patient (3\%) had a partial response and $4(12 \%)$ had stable disease [82].

\subsection{3- mTOR inhibitors}

The mammalian target of rapamycin (mTOR) is an intracellular serine/threonine protein kinase positioned at a central point in a variety of cellular signaling cascades. The established involvement of mTOR activity in the 
Table 7 Treatment recommendations:

\begin{tabular}{|c|c|c|c|}
\hline \multicolumn{2}{|c|}{ First line treatment } & \multicolumn{2}{|c|}{ Second and third line treatments } \\
\hline Patients eligible to cisplatin & $\begin{array}{l}\text { Unfit } \\
\text { patients }\end{array}$ & Cisplatin sensitive disease & Cisplatin refractory disease \\
\hline $\begin{array}{l}\text { MVAC, HD-MVAC, GC, and } \\
\text { DD-GC }\end{array}$ & $\begin{array}{l}\text { GCa and } \\
\text { MCAVI }\end{array}$ & $\begin{array}{l}\text { Cisplatin based doublet not used in first } \\
\text { line }\end{array}$ & $\begin{array}{l}\text { Vinflunine, Paclitaxel-Gemcitabine, and all actives drugs } \\
\text { not used }\end{array}$ \\
\hline
\end{tabular}

cellular processes that contribute to the development and progression of cancer has identified mTOR as a major link in tumorigenesis. Consequently, inhibitors of mTOR, have been developed and assessed for their safety and efficacy in patients with cancer [83].

* Everolimus RAD001 AFINITOR ${ }^{\circledR}$ Everolimus is an oral rapamycin compound targeting and inhibiting the PI3K/Akt/mTOR pathway a central regulator of cell growth, proliferation, survival, and angiogenesis. It is currently indicated in second line treatment of metastatic renal cancer after failure of one tyrosine kinase inhibitor. The RAD001 was tested at a dose of $10 \mathrm{mg}$ daily in 2 phase II trials in second line treatment. The results of these 2 trials were presented this year at ASCO 2011 and showed limited activity of Everolimus $(\mathrm{PR}=8 \%$; PFS $=3.3$ months; $\mathrm{OS}=10.5$ months, in one study) [84].

\subsection{4- Histone deacetylase inhibitors}

Histone deacetylases (HDACs) can regulate expression of tumor suppressor genes and activities of transcriptional factors involved in both cancer initiation and progression through alteration of either DNA or the structural components of chromatin. Recently, the role of gene repression through modulation such as acetylation in cancer patients has been clinically validated with several inhibitors of HDACs. In bladder cancer, Belinostat (PXD101) a HDACs inhibitor, was shown to be active according to several preclinical studies $[85,86]$.

\section{5- Treatment recommandations (Table 7)}

\section{(A) First line treatment}

In metastatic setting, chemotherapy based on cisplatin should be considered as standard treatment of choice for patients with good performance status (0-1) and good renal function-Glomerular filtration rate (GFR) $>60 \mathrm{~mL} /$ min. MVAC, HD-MVAC, gemcitabine-cisplatin and dosedense gemcitabine-cisplatin should be considered as four standard first-line chemotherapy treatments for metastatic bladder TCC.

Taxane-based doublets are inferior to the standard MVAC and should not be used in first-line.

Carboplatin-based combinations are inferior to cisplatin based regimens and should be only used in unfit patients.

The platinum-free doublets are efficient and should be evaluated in randomized phase III trials.
The triplet combinations are more toxic but not more effective, and should not be used in practice.

The sequential protocols are more toxic but not more effective and should be evaluated in randomized phase III trials.

The role of targeted therapies in the management of metastatic bladder TCC has not yet been defined. Nevertheless, targeting angiogenesis seem to be very promising.

\section{(B) Second and third line treatments}

For patients with platinum sensitive disease, a second line treatment based on cisplatin should be used in patient eligible to cisplatin. For cisplatin ineligible patients, a regimens based on carboplatin can be used.

Vinflunine and gemcitabine-paclitaxel are 2 reasonable therapeutic options in patients with cisplatin refractory disease.

All active drugs can be used in second and third line treatments.

\section{6 - Conclusions}

Chemotherapy plays a major role in the management of bladder cancer $[87,88]$. In the metastatic setting, palliative chemotherapy based on cisplatin type MVAC, HD-MVAC, or GC or DD-GC remains the treatment of choice. In unfit patients, Carboplatin based chemotherapy type Gemcitabin-Carboplatin or Methotrexate-Carboplatin-Vinblatine (MCAVI) is a good option for these patients. Novel therapies, targeting angiogenesis, have been shown to be very promising. Therapeutic investigations should be continued with the development of new drugs and targeted therapies to improve treatment results in the metastatic bladder cancer.

\section{Abbreviations}

AKT: Protein Kinase B; ASCO: American society of clinical oncology; AUC: air under the curve; CaPG: carboplatin, Paclitaxel, and gemcitabine; CISCA: cisplatin, cyclophosphamide, and doxorubicin; C-Kit: Stem Cell Factor; CMV: cisplatin, methotrexate, and vinblastine; CR: complete response; DC: docetaxel plus cisplatin; DD-GC: dose dense GC; EDC: epirubicin, docetaxel, and cisplatin; EGFR: epidermal growth factor receptor; EORT: European organization of research and treatment; FDA: food and drug administration FGFR: fibroblast growth factor receptor; GC: gemcitabine plus cisplatin; GCa: gemcitabine plus carboplatin; GCSF: granulocyte colony stimulating factor; GIST: gastrointestinal stromal tumor; HER2: human epidermal growth factor receptor 2; ITCa: ifosfamide, paclitaxel, and carboplatin; ITP: ifosfamide, paclitaxel, and cisplatin; MCAVI: methotrexate, carboplatin, and vinblastine; M-GP: methotrexate, gemcitabine, paclitaxel; mTOR: mammalian target of 
rapamycin; MVAC: methotrexate, vinblastine, doxorubicin, and cisplatin; HDMVAC: high dose MVAC; ORR: overall response rate; OS: overall survival; PCa: paclitaxel plus carboplatin; PCG: paclitaxel, cisplatin, and gemcitabine; PDGFR: platelet derived growth factor; PFS: progression free survival; PI3K: phosphoinositide 3-kinases; PR: partial response; RAF: human protooncogene serine/threonine-protein kinase; S: stabilization; TCC: transitional cell carcinoma; TTP: time to progression VEGFR: vascular endothelial growth factor receptor

\section{Acknowledgements}

We sincerely thank Mohammed Ismaili, Professor of Microbiology from Moulay Ismail University, Meknes, Morocco.

\section{Author details}

${ }^{1}$ Medical Oncology, Centre régional d'oncologie, Agadir, Morocco. ${ }^{2}$ Medical Oncology, National institute of oncology, Rabat, Morocco. ${ }^{3}$ Medical Oncology, Centre Léon-Bérard, Lyon, France.

\section{Authors' contributions}

$\mathrm{NI}$ is involved in concept design, in data collection, drafting and critically revising the manuscript. MA is involved in data collection; AF is involved in data collection and critically revising the manuscript.

All authors read and approved the final manuscript.

\section{Competing interests}

The authors declare that they have no competing interests.

Received: 2 August 2011 Accepted: 9 September 2011

Published: 9 September 2011

\section{References}

1. Jemal A, Bray F, Center MM, Ferlay J, Ward E, Forman D: Global cancer statistics. CA Cancer J Clin 2011, 61(2):69-90, Epub 2011 Feb 4.

2. Rathkopf D, Scher HI: Multidisciplinary Management of Genitourinary Malignancies in Malcolm R. Alison, editor. The cancer handbook. 2 edition. London: Jon Wiley \& Son; 2007, 1432-52.

3. Wallerand $\mathrm{H}$ : Intravesical chemotherapy and bladder cancer. Prog Uro 2009, 19(12):868-71.

4. Boyle H, Fléchon A, Droz JP: Treatment of uncommon malignant tumours of the bladder. Curr Opin Urol 2011, 21(5):309-14.

5. Ismaili N, Arifi S, Flechon A, El Mesbahi O, Blay JY, Droz JP, et al: Small cell cancer of the bladder: pathology, diagnosis, treatment and prognosis. Bull Cancer 2009, 96(6):E30-44.

6. Bellmunt J, Choueiri TK, Fougeray $R$, Schutz FA, Salhi $Y$, Winquist E, Culine $S$, von der Maase H, Vaughn DJ, Rosenberg JE: Prognostic factors in patients with advanced transitional cell carcinoma of the urothelial tract experiencing treatment failure with platinum-containing regimens. J Clin Oncol 2010, 28(11):1850-5, Epub 2010 Mar 15.

7. Gagliano R, Levin H, El-Bolkainy MN, Wilson HE, Stephens RL, Fletcher WS, et al: Adriamycin versus adriamycin plus cis-diamminedichloroplatinum (DDP) in advanced transitional cell bladder carcinoma. A Southwest Oncology Group study. Am J Clin Oncol 1983, 6(2):215-8.

8. Soloway MS, Einstein A, Corder MP, Bonney W, Prout GR Jr, Coombs J: A comparison of cisplatin and the combination of cisplatin and cyclophosphamide in advanced urothelial cancer. A National Bladder Cancer Collaborative Group A Study. Cancer 1983, 52(5):767-72.

9. Harke WG, Meyers FJ, Freiha FS, Palmer JM, Shortliffe LD, Hannigan JF, et al: Cisplatin, methotrexate, and vinblastine (CMV): an effective chemotherapy regimen for metastatic transitional cell carcinoma of the urinary tract. A Northern California Oncology Group study. J Clinl Oncol 1985, 1463-70.

10. Troner M, Birch R, Omura GA, Williams S: Phase III comparison of cisplatin alone versus cisplatin, doxorubicin and cyclophosphamide in the treatment of bladder (urothelial) cancer: a Southeastern Cancer Study Group trial. J Urol 1987, 137(4):660-2.

11. Sternberg CN, Yagoda A, Scher HI, Watson RC, Ahmed T, Weiselberg LR, et al: Preliminary results of M-VAC (methotrexate, vinblastine, doxorubicin and cisplatin) for transitional cell carcinoma of the urothelium. J Urol 1985, 133(3):403-7.

12. Sternberg CN: A critical review of the management of bladder cancer. Crit Rev Oncol Hematol 1999, 31(3):193-207.
13. Logothetis CJ, Dexeus FH, Finn L, Sella A, Amato RJ, Ayala AG, et al: A prospective randomized trial comparing MVAC and CISCA chemotherapy for patients with metastatic urothelial tumors. J Clin Oncol 1990, 8(6):1050-5.

14. Loehrer PJ, Einhorn LH, Elson PJ, Crawford ED, Kuebler P, Tannock I, et al: A randomized comparison of cisplatin alone or in combination with methotrexate, vinblastine, and doxorubicin in patients with metastatic urothelial carcinoma: a cooperative group study. J Clin Oncol 1992, 10(7):1066-73.

15. Sternberg CN, de Mulder PH, Schornagel JH, Théodore C, Fossa SD, van Oosterom AT, et al: Randomized phase III trial of high-dose-intensity methotrexate, vinblastine, doxorubicin,and cisplatin (MVAC) chemotherapy and recombinant human granulocyte colony-stimulating factor versus classic MVAC in advanced urothelial tract tumors: European Organization for Research and Treatment of Cancer Protocol no. 30924. J Clin Oncol 2001, 19:2638-46.

16. Sternberg CN, de Mulder P, Schornagel JH, Theodore C, Fossa SD, van Oosterom AT, et al: Seven year update of an EORTC phase III trial of high-dose intensity M-VAC chemotherapy and G-CSF versus classic MVAC in advanced urothelial tract tumours. Eur J Cancer 2006, 42:50-4.

17. Bellmunt J, Albiol S, de Olano AR, Pujadas J, Maroto P: Spanish Oncology Genitourinary Group (SOGUG). Gemcitabine in the treatment of advanced transitional cell carcinoma of the urothelium. Ann Oncol 2006, 17:113-7.

18. von der Maase H, Hansen SW, Roberts JT, Dogliotti L, Oliver T, Moore MJ, Bodrogi I, Albers P, Knuth A, Lippert CM, Kerbrat P, Sanchez Rovira P, Wersall P, Cleall SP, Roychowdhury DF, Tomlin I, Visseren-Grul CM, Conte PF: Gemcitabine and cisplatin versus methotrexate, vinblastine, doxorubicin, and cisplatin in advanced or metastatic bladder cancer: results of a large, randomized, multinational, multicenter, phase III study. J Clin Oncol 2000, 18(17):3068-77.

19. von der Maase H, Sengelov L, Roberts JT, Ricci S, Dogliotti L, Oliver T, et al: Long-term survival results of a randomized trial comparing gemcitabine plus cisplatin, with methotrexate, vinblastine, doxorubicin, plus cisplatin in patients with bladder cancer. J Clin Oncol 2005, 4602-08.

20. Bamias A, Karadimou A, Lampaki S, Aravantinos G, Xanthakis Papandreou C, et al: Hellenic Cooperative Oncology Group (HeCOG), Athens, Greece. Prospective, randomized phase III study comparing two intensified regimens (methotrexate/vinblastine/doxorubicin hydrochloride/cisplatin [MVAC] versus gemcitabine/cisplatin) in patients with inoperable or recurrent urothelial cancer. J Clin Oncol 2011, 29(suppl; abstr 4510)

21. Burch PA, Richardson RL, Cha SS, Sargent DJ, Pitot HC, Kaur JS, et al: Phase II study of paclitaxel and cisplatin for advanced urothelial cancer. J Urol 2000, 164(5):1538-42.

22. Dreicer R, Manola J, Roth BJ, Cohen MB, Hatfield AK, Wilding G: Phase II study of cisplatin and paclitaxel in advanced carcinoma of the urothelium: an Eastern Cooperative Oncology Group Study. J Clin Oncol 2000, 18:1058-61.

23. Dimopoulos MA, Bakoyannis C, Georgoulias V, Papadimitriou C, Moulopoulos LA, Deliveliotis $C$, et al: Docetaxel and cisplatin combination chemotherapy in advanced carcinoma of the urothelium: a multicenter phase II study of the Hellenic Cooperative Oncology Group. Ann Oncol 1999, 10:1385-8.

24. Garcia del Muro X, Marcuello E, Gumá J, Paz-Ares L, Climent MA, Carles J, et al: Phase II multicentre study of docetaxel plus cisplatin in patients with advanced urothelial cancer. Br J Cancer 2002, 86:326-30.

25. Sengelov L, Kamby C, Lund B, Engelholm SA: Docetaxel and cisplatin in metastatic urothelial cancer: a phase II study. J Clin Oncol 1998, 16:3392-7.

26. Bamias A, Aravantinos G, Deliveliotis C, Bafaloukos D, Kalofonos C, Xiros N, et al: Docetaxel and cisplatin with granulocyte colony-stimulating factor (G-CSF) versus MVAC with G-CSF in advanced urothelial carcinoma: a multicenter, randomized phase III study from the Hellenic Cooperative OncologyGroup. J Clin Oncol 2004, 22:220-8.

27. Waxman J, Barton C: Carboplatin-based chemotherapy for bladder cancer. Cancer Treat Rev 1993, 19(Suppl. C):21-5.

28. Redman BG, Smith DC, Flaherty L, Du W, Hussain M: Phase II trial of paclitaxel and carboplatin in the treatment of advanced urothelial carcinoma. J Clin Oncol 1998, 16:1844-8.

29. Small EJ, Lew D, Redman BG, Petrylak DP, Hammond N, Gross HM, et al: Southwest Oncology Group Study of paclitaxel and carboplatin for 
advanced transitional-cell carcinoma: the importance of survival as a clinical trial end point. J Clin Oncol 2000, 18:2537-44.

30. Vaughn DJ, Malkowicz SB, Zoltick B, Mick R, Ramchandani P, Holroyde C, et al: Paclitaxel plus carboplatin in advanced carcinoma of the urothelium: an active and tolerable outpatient regimen. $J$ Clin Oncol 1998, 16:255-60.

31. Dreicer R, Manola J, Roth BJ, See WA, Kuross S, Edelman MJ, Hudes GR, Wilding G: Phase III trial of methotrexate, vinblastine, doxorubicin, and cisplatin versus carboplatin and paclitaxel in patients with advanced carcinoma of the urothelium. Cancer 2004, 100(8):1639-45.

32. Bellmunt J, de Wit R, Albanell J, Baselga J: A feasibility study of carboplatin with fixed dose of gemcitabine in "unfit" patients with advanced bladder cancer. Eur J Cancer 2001, 37:2212-5.

33. Nogué-Aliguer M, Carles J, Arrivi A, Juan O, Alonso L, Font A, et al: Gemcitabine and carboplatinin advanced transitional cell carcinoma of the urinary tract: an alternative therapy. Cancer 2003, 97:2180-6.

34. Shannon C, Crombie C, Brooks A, Lau H, Drummond M, Gurney H: Carboplatin and gemcitabine in metastatic transitional cell carcinoma of the urothelium: effective treatment of patients with poor prognostic features. Ann Oncol 2001, 12:947-52.

35. Dogliotti L, Cartenì G, Siena S, Bertetto O, Martoni A, Bono A, et al: Gemcitabine plus cisplatin versus gemcitabine plus carboplatin as firstline chemotherapy in advanced transitional cell carcinoma of the urothelium: results of a randomized phase 2 trial. Eur Urol 2007, 52(1):134-41.

36. Winquist E, Vokes E, Moore MJ, Schumm LP, Hoving K, Stadler WM: A Phase II study of oxaliplatin in urothelial cancer. Urol Oncol 2005, 23(3):150-4

37. De Santis M, Bellmunt J, Mead G, Kerst JM, Leahy MG, Daugaard G, et al Randomized phase II/III trial comparing gemcitabine/carboplatin (GC) and methotrexate/carboplatin/vinblastine (M-CAVI) in patients (pts) with advanced urothelial cancer (UC) unfit for cisplatin-based chemotherapy (CHT): Phase III results of EORTC study 30986. J Clin Oncol 2010, 28:18s: abstract LBA4519.

38. Kaufman DS, Carducci MA, Kuzel TM, Todd MB, Oh WK, Smith MR, et al: A multi-institutional phase II trial of gemcitabine plus paclitaxel in patients with locally advanced or metastatic urothelial cancer. Urol Oncol 2004, 22(5):393-7.

39. Li J, Juliar B, Yiannoutsos C, Ansari R, Fox E, Fisch MJ, et al: Weekly paclitaxel and gemcitabine in advanced transitional-cell carcinoma of the urothelium: a phase II Hoosier Oncology Group study. J Clin Oncol 2005, 23:1185-91.

40. Meluch AA, Greco FA, Burris HA, O'Rourke T, Ortega G, Steis RG, et al: Paclitaxel and gemcitabine chemotherapy for advanced transitional-cell carcinoma of the urothelial tract: a phase II trial of the Minnie pearl cancer research network. J Clin Oncol 2001, 19:3018-24.

41. Kaufman DS, Carducci MA, Kuzel TM, Todd MB, Oh WK, Smith MR, et al: A multi-institutional phase II trial of gemcitabine plus paclitaxel in patients with locally advanced or metastatic urothelial cancer. Urol Oncol 2004, 22:393-7.

42. Ardavanis A, Tryfonopoulos D, Alexopoulos A, Kandylis C, Lainakis G, Rigatos G: Gemcitabine and docetaxel as first-line treatment for advanced urothelial carcinoma: a phase II study. Br J Cancer 2005, 92:645-50

43. Dumez H, Martens M, Selleslach J, Guetens G, De Boeck G, Aerts R, et al: Docetaxel and gemcitabine combination therapy in advanced transitional cell carcinoma of the urothelium: results of a phase II and pharmacologic study. Anticancer Drugs 2007, 18:211-8.

44. Gitlitz BJ, Baker C, Chapman Y, Allen HJ, Bosserman LD, Patel R, et al: A phase II study of gemcitabine and docetaxel therapy in patients with advanced urothelial carcinoma. Cancer 2003, 98:1863-9.

45. Li S, Dreicer R, Roth B, Manoloa J, Cooney M, Wilding G: Phase II trial of pemetrexed disodium and gemcitabine in advanced carcinoma of the urothelium (E4802): A trial of the Eastern Cooperative Oncology Group. $J$ Clin Oncol 2007, 25, abstract 5079.

46. von der Maase H, Lehmann J, Gravis G, Joensuu H, Geertsen PF, Gough J, et al: A phase II trial of pemetrexed plus Gemcitabine in locally advanced and/or metastatic transitional cell carcinoma of the urothelium. Ann Oncol 2006, 17:1533-8.

47. Bellmunt J, Guillem V, Paz-Ares L, González-Larriba JL, Carles J, BatisteAlentorn $E$, et al: Phase I-II study of paclitaxel, cisplatin, and gemcitabine in advanced transitional-cell carcinoma of the urothelium. Spanish Oncology Genitourinary Group. J Clin Oncol 2000, 18(18):3247-55.

48. Bellmunt J, von der Maase H, Mead GM, Heyer J, Houede N, Paz-Ares LG, et al: Randomized phase III study comparing paclitaxel/cisplatin/ gemcitabine (PCG) and gemcitabine/cisplatin (GC) in patients with locally advanced (LA) or metastatic (M) urothelial cancer without prior systemic therapy; EORTC30987/Intergroup Study. J Clin Oncol 2007, 25, abstract LBA5030.

49. Bajorin DF, McCaffrey JA, Dodd PM, Hilton S, Mazumdar M, Kelly WK, et al: Ifosfamide, paclitaxel, and cisplatin for patients with advanced transitional cell carcinoma of the urothelial tract: final report of a phase II trial evaluating two dosing schedules. Cancer 2000, 88:1671-8.

50. Hussain M, Vaishampayan U, Du W, Redman B, Smith DC: Combination paclitaxel, carboplatin, and gemcitabine is an active treatment for advanced urothelial cancer. J Clin Oncol 2001, 19:2527-33.

51. Hainsworth JD, Meluch AA, Litchy S, Schnell FM, Bearden JD, Yost K, et al: Paclitaxel, carboplatin, and gemcitabine in the treatment of patients with advanced transitional cell carcinoma of the urothelium. Cancer 2005, 103(11):2298-303

52. Edelman MJ, Meyers FJ, Miller TR, William SG, Gandour Edwards R, De Vere white R: Phase I/II study of paclitaxel, carboplatin ant methotrexate in advanced transitional cell carcinoma: a well tolerated regimen with activity independent of p53 mutation. Urology 2000, 55:521-5.

53. Tu SM, Hossan E, Amato R, Kilbourn R, Logothesis: Paclitaxel, cisplatin and methotrexate combination chemotherapy is active in the treatment of refractory urothelial malignancies. J Urol 1995, 154:1719-22.

54. Law LY, Lara PN, Meyers FJ, Dawson NA, Edelman MJ: Platinum (PLAT) Free Combination Chemotherapy in Locally Advanced and Metastatic Transitional Cell Carcinoma (TCC): Phase I/II Trial of Gemcitabine (GEM), Paclitaxel (TAX), Methotrexate (MTX). J Clin Oncol 2001, 20, abstract 767.

55. Pectasides D, Visvikis A, Aspropotamitis A, Halikia A, Karvounis N, Dimitriadis M, et al: Chemotherapy with cisplatin, epirubicin and docetaxel in transitional cell urothelial cancer. Phase II trial. Eu J Cancer 2000, 36:74-9.

56. Milowsky MI, Nanus DM, Maluf FC, Mironov S, Shi W, lasonos A, Riches J, Regazzi A, Bajorin DF: Final results of sequential doxorubicin plus gemcitabine and ifosfamide, paclitaxel, and cisplatin chemotherapy in patients with metastatic or locally advanced transitional cell carcinoma of the urothelium. J Clin Oncol 2009, 27(25):4062-7, Epub 2009 Jul 27.

57. Galsky MD, lasonos A, Mironov S, Scattergood J, Boyle MG, Bajorin DF: Phase II trial of dose-dense doxorubicin plus gemcitabine followed by paclitaxel plus carboplatin in patients with advanced urothelial carcinoma and impaired renal function. Cancer 2007, 109(3):549-55.

58. Di Lorenzo G, Autorino R, Giordano A, Giuliano M, D'Armiento M, Bianco AR, et al: FOLFOX-4 in pretreated patients with advanced transitional cell carcinoma of the bladder. Jpn J Clin Oncol 2004, 34:747-50.

59. Khorsand M, Lange J, Feun L, Clendeninn NJ, Collier M, Wilding G: Phase II trial of oral piritrexim in advanced, previously treated transitional cell cancer of bladder. Invest New Drugs 1997, 15:157-63.

60. Sweeney CJ, Roth BJ, Kabbinavar FF, Vaughn DJ, Arning M, Curiel RE, et al: Phase II study of pemetrexed for second-line treatment of transitional cell cancer of the urothelium. I Clin Oncol 2006, 24:3451-7.

61. Seo YR, Kim SH, Kim HJ, Kim CK, Park SK, Koh ES, Hong DS: Complete response to FOLFOX4 therapy in a patient with advanced urothelial cancer: a case report. J Hematol Oncol 2010, 3:4.

62. Bellmunt J, Théodore C, Demkov T, Komyakov B, Sengelov L, Daugaard G, et al: Phase III trial of vinflunine plus best supportive care compared with best supportive care alone after a platinum-containing regimen in patients with advanced transitional cell carcinoma of the urothelial tract. J Clin Oncol 2009, 27(27):4454-61.

63. Albers P, Park SI, Niegisch G, Fechner G, Steiner U, Lehmann J, Heimbach D, Heidenreich A, Fimmers R, Siener R, AUO Bladder Cancer Group: Randomized phase III trial of 2nd line gemcitabine and paclitaxel chemotherapy in patients with advanced bladder cancer: short-term versus prolonged treatment [German Association of Urological Oncology (AUO) trial AB 20/99]. Ann Oncol 2011, 22(2):288-94, Epub 2010 Aug 2.

64. Quinn DI, Aparicio A, Tsao-Wei DD, Groshen SG, Dorff TB, Synold TW, et al Phase II study of eribulin (E7389) in patients (pts) with advanced urothelial cancer (UC)-Final report: A California Cancer Consortium-led NCI/CTEP-sponsored trial. J Clin Oncol 2010, 28, abstract 4539. 
65. [http://www.clinicaltrials.gov/ct2/results?term=\%22bladder+cancer\%22 + metastatic+disease]

66. Hahn NM, Stadler WM, Zon RT, Waterhouse DM, Picus j, Nattam SR, et al: Mature results from Hoosier Oncology Group GU04-75 phase II trial of cisplatin (C), gemcitabine $(\mathrm{G})$, and bevacizumab $(\mathrm{B})$ as first-line chemotherapy for metastatic urothelial carcinoma (UC). J Clin Oncol 2010, 28, abstract 4541.

67. Gallagher DJ, Milowsky MI, Gerst SR, Ishill N, Riches J, Regazzi A, et al: Phase II study of sunitinib in patients with metastatic urothelial cancer. J Clin Oncol 2010, 28(8):1373-9

68. Gallagher DJ, Milowsky MI, Gerst SR, Tickoo S, Ishill N, Regazzi A, et al: A phase II study of sunitinib on a continuous dosing schedule in patients (pts) with relapsed or refractory urothelial carcinoma (UC). 2009 ASCO Annual Meeting. J Clin Oncol 2009, 27, abstract 5072.

69. Bradley D, Daignault S, Smith DC, Nanus D, Tagawa S, Stadler WM, et al: Maintenance sunitinib postchemotherapy (CT) in patients (pts) with advanced urothelial carcinoma (UC): a randomized placebo controlled phase II trial. J Clin Oncol 2009, 27, abstract 5073.

70. Galsky MD, Sonpavde G, Hellerstedt BA, McKenney SA, Hutson TE, Rauch MA, et al: Phase II study of gemcitabine, cisplatin, and sunitinib in patients with advanced urothelial carcinoma (UC). J Clin Oncol 2010, 28, abstract 4573 .

71. Bellmunt J, Gonzalez-Larriba JL, Maroto JP, Carles J, Castellano DE, Mellado B, et al: First-line treatment with sunitinib monotherapy in patients with advanced urothelial cancer ineligible for cisplatin-based chemotherapy: Pretreatment levels of IL8 and Hounsfield units as predictors of clinical benefit. J Clin Oncol 2010, 28, abstract 4540.

72. Dreicer R, Li H, Stein MN, DiPaola RP, Eleff M, Roth BJ, et al: Phase II trial of sorafenib in advanced carcinoma of the urothelium (E 1804): a trial of the Eastern Cooperative Oncology Group. J Clin Oncol 2008, 26, abstract 5083.

73. Krege S, Rexer H, vom Dorp F, Albers P, De Geeter P, Klotz T: Gemcitabine and cisplatin with or without sorafenib in urothelial carcinoma (AUO-AB 31/05). J Clin Oncol 2010, 28, abstract 4574.

74. Milowsky Ml, Carlson GL, Shi MM, Urbanowitz G, Zhang Y, Sternberg CN Open-label phase II trial of dovitinib (TKI258) in advanced urothelial carcinoma patients with either mutated or wild-type FGFR3. I Clin Oncol 2011, 29(suppl; abstr TPS186).

75. Lönn U, Lönn S, Friberg S, Nilsson B, Silfverswärd C, Stenkvist B: Prognostic value of amplification of c-erbB-2 in bladder carcinoma. Clin Cancer Res 1995, 1:1189-94

76. Vollmer RT, Humphrey PA, Swanson PE, Wick MR, Hudson ML: Invasion of the bladder by transitional cell-carcinoma: its relation to histologic grade and expression of p53, MIB-1, c-erbB-2, epidermal growth factor receptor, and bcl-2. Cancer 1998, 82:715-23.

77. Jimenez RE, Hussain M, Bianco FJ Jr, Vaishampayan U, Tabazcka P, Sakr WA, et al: HER2/neu overexpression in muscleinvasive urothelial carcinoma of the bladder: prognostic significance and comparative analysis in primary and metastatic tumors. Clin Cancer Res 2001, 7:2440-7.

78. De Pinieux G, Colin D, Vincent-Salomon A, Couturier J, AmsellemOuazana $D$, Beuzeboc $P$, et al: Confrontation of immunohistochemistry and fluorescent in situ hybridization for the assessment of HER-2/neu (cerbB-2) status in urothelial carcinoma. Virchows Arch 2004, 444:415-9.

79. Hussain MH, MacVicar GR, Petrylak DP, Dunn RL, Vaishampayan U, Lara PN $\mathrm{Jr}$, et al: Trastuzumab, paclitaxel, carboplatin, and gemcitabine in advanced human epidermalgrowth factor receptor-2/neu-positive urothelial carcinoma: results of a multicenter phase II National Cancer Institute trial. J Clin Oncol 2007, 25:2218-24.

80. Petrylak D, Faulkner JR, Van Veldhuizen PJ, Mansukhani M, Crawford ED: Evaluation of ZD1839 for advanced transitional cell carcinoma (TCC) of the urothelium: a Southwest Oncology Group Trial. J Clin Oncol 2003, 22, abstract 1619 .

81. Philips GK, Halabi S, Sanford BL, Bajorin D, Small EJ, Cancer and Leukemia Group B: A phase II trial of cisplatin (C), gemcitabine (G) and gefitinib for advanced urothelial tract carcinoma: results of Cancer and Leukemia Group B (CALGB) 90102. Ann Oncol 2009, 20(6):1074-9.

82. Wülfing C, Machiels JP, Richel DJ, Grimm MO, Treiber U, De Groot MR, et al A single-arm, multicenter, open-label phase 2 study of lapatinib as the second-line treatment of patients with locally advanced or metastatic transitional cell carcinoma. Cancer 2009, 115(13):2881-90.
83. Yuan R, Kay A, Berg WJ, Lebwohl D: Targeting tumorigenesis: development and use of mTOR inhibitors in cancer therapy. $J$ Hematol Oncol 2009, 2:45.

84. Milowsky MI, Trout A, Regazzi AM, Garcia-Grossman I, Flaherty A, Tickoo S, et al: H. Phase II study of everolimus (RAD001) in metastatic transitional cell carcinoma (TCC) of the urothelium. J Clin Oncol 2010, 28, abstract TPS229.

85. Tan J, Cang S, Ma Y, Petrillo RL, Liu D: Novel histone deacetylase inhibitors in clinical trials as anti-cancer agents. $J$ Hematol Oncol 2010, 3:5.

86. Xu XS, Wang L, Abrams J, Wang G: Histone deacetylases (HDACs) in XPC gene silencing and bladder cancer. J Hematol Oncol 2011, 4:17.

87. Ismaili N, Amzerin M, Elmajjaoui S, Droz JP, Flechon A, Errihani H: The role of chemotherapy in the management of bladder cancer. Prog Urol 2011, 21(6):369-82

88. Ismaili N, Elmajjaoui S, Bensouda Y, Belbaraka R, Abahssain H, Allam W, et al Neoadjuvant or adjuvant chemotherapy: what is the best treatment of muscle invasive bladder cancer? Oncol Rev 2011.

doi:10.1186/1756-8722-4-35

Cite this article as: Ismaili et al:: Chemotherapy in advanced bladder cancer: current status and future. Journal of Hematology \& Oncology 2011 4:35

\section{Submit your next manuscript to BioMed Central and take full advantage of:}

- Convenient online submission

- Thorough peer review

- No space constraints or color figure charges

- Immediate publication on acceptance

- Inclusion in PubMed, CAS, Scopus and Google Scholar

- Research which is freely available for redistribution 